Volume 2, Issue 2, pages 197-208

p-ISSN 2655-8564, e-ISSN 2685-9432

\title{
Information Technology and Learning Methodology amid the COVID-19 Pandemic
}

\author{
Hari Suparwito \\ Department of Informatics, Faculty of Science and Technology, \\ Sanata Dharma University, Yogyakarta, Indonesia, \\ Corresponding Author: shirsj@jesuits.net
}

(Received 05-10-2020; Revised 09-11-2020; Accepted 09-11-2020)

\begin{abstract}
The impact of the COVID-19 pandemic on the education sector caused schools and universities are closed. Then, teaching and learning are delivered by an online method through information and communication technology. Some issues have emerged, especially on delivering materials and the minimum requirements of online learning. The study aims to review learning methodologies and the role of information and communication technology for future learning. Heutagogy and Computational Thinking have been selected as the learning methodology for approaching digital native generation. It is no doubt that the significant role in undertaking online education is information and communication technology. Therefore, we suggested some tools to enhance learning systems, such as gamification learning, virtual labs, and social media. We also discussed new learning media using information and communication technology in education. The study's contribution is to describe technology's role in the future learning system to be used by decision-makers in implementing e-learning better.
\end{abstract}

Keywords: COVID-19, computational thinking, e-learning, heutagogy, internet technology, learning media 


\section{International Journal of Applied Sciences and Smart Technologies}

Volume 2, Issue 2, pages 197-208

p-ISSN 2655-8564, e-ISSN 2685-9432

\section{Introduction}

Covid-19 pandemic is affecting human lives around the world. Just a week after WHO declared the coronavirus disease 2019 (COVID-19) outbreak to be a pandemic on March 12, 2020, the U.N. Educational, Scientific and Cultural Organization estimated that 107 countries had implemented national school closures, affecting to 862 million children and young people cannot perform a regular education such as going to school, learning in the class and playing in the yard [1]. Governments have temporarily closed schools to contain the spread of the virus. This action intends to prevent the spread of the virus within institutions and prevent carriage to vulnerable individuals. However, it also has had an impact on society and education sections. The school closures influence $80 \%$ of children worldwide even though some debates are ongoing about school closures' effectiveness on virus transmission [2].

In response to the COVID-19 virus, online instruction and teaching have been proposed, and everyone in the school community needed to make some adjustments in education. Many changes imposed on us by the COVID-19 pandemic are shifts in how educational content is delivered, with a migration away from the conventional inclassroom experience to more technology-based virtual learning experiences [3].

The study examines how technology in the COVID-19 time has changed the schools' conventional teaching and learning process. We discussed the role of information communication technology (ICT), especially as the supporting system on successful teaching and learning when the school disclosure in the COVID-19 pandemic. The study's contributions are first to see the possibilities in using some learning methodologies related to ICT to address the coop when the school closed during the COVID-19 pandemic. Secondly, showing the potential factors should be considered when we want to implement e-learning and information technology to support our teaching and learning process.

\section{Teaching and Learning Methodologies}

When the schools are closed, and teaching and learning processes are not delivered using the conventional way, there is a possible way to teach and learn using ICT. 


\section{International Journal of Applied Sciences and Smart Technologies}

Volume 2, Issue 2, pages 197-208

p-ISSN 2655-8564, e-ISSN 2685-9432

However, implementing ICT in education is not about the hardware and what kind of technology used, but firstly, it is about the teaching and learning methodology. In the last two decades, some teaching and learning methodologies related to ICT have been used in education. Some methodologies have been created, such as Heutagogy and Computational Thinking. Hence, the methodologies describe users' characteristics and the materials that should be delivered based on ICT.

To understand more deeply, below, we pointed out the essential things in that methodologies.

\subsection{Heutagogy}

Learning happens due to some experience inside the educational setting (i.e., the classroom or the e-learning site); however, in Heutagogy, that has happened contrarily. Learners choose and undertake according to what they want [4]. As a particular interest in distance learning, Heutagogy is defined as the study of self-determined learning. Distance education and Heutagogy are intended for mature adult learners [5]. In Heutagogy, the educational process changes from teachers to learners. Heutagogy represents a change from teacher-centered learning to learner-centered learning [6].

Heutagogy cannot be separated from Andragogy. Going back to the early seventies, Knowles introduced Andragogy. Andragogy acknowledges that life experience could increase motivation and relevance in learning environments. In other words, adults can be more inclined to be self-directed in their learning, even though the curricula and the learning experience are still highly teacher-driven and directed [7].

Andragogy was developed based on adult learners' characteristics such as the Need to Know, Self-concept, Experience, Readiness -orientation-motivation to learn as a mature person. The learning shifts from one of subject-centeredness to one of problem centeredness. This assumption on Andragogy has become a good platform for applying e-learning. As we know, in e-learning methods, the interaction between teachers and students occurs in the virtual and independent meeting.

Concerning e-learning, Heutagogy could be seen in two levels of thinking. The first is related to do with the acquisition of knowledge. The second one is that the whole learning experience becomes much less predictable, and the learner's needs and motivation shift rapidly and not necessarily in concert with the teacher's aims or the 


\section{International Journal of Applied Sciences and Smart Technologies}

Volume 2, Issue 2, pages 197-208

p-ISSN 2655-8564, e-ISSN 2685-9432

curriculum. Learning will probably enhance our excitement and enjoyment since matching the learners' needs and how they want to achieve their goals [8].

\subsection{Computational Thinking}

Another central aspect of the modern teaching concept is to deliver the subjects using a computational thinking concept. According to Wing [9], computational thinking focuses on the process of abstraction since the use of abstraction, automation, and analysis in problem-solving has become a crucial part of the modern era [10]. In general, computational thinking is the thought processes involved in formulating a problem and expressing the solution to carry out a computer or human effectively. Computational thinking comes before any computing technology, thought of by a human, knowing full well the power of automation.

Focusing on the importance of computational thinking in the modern era of education, in 2016 International Society for Technology in Education (ISTE) has released a learning standard for students. The standard has seven parts that should be on the class teaching (see Figure 1). The standard describes the achievement of learning for the students in the future. It is interesting, ISTE included computational thinking as one factor in teaching to the digital native generation. Two of seven aspects in the student standard referred to ICT, namely Computational Thinker and Digital Citizen.

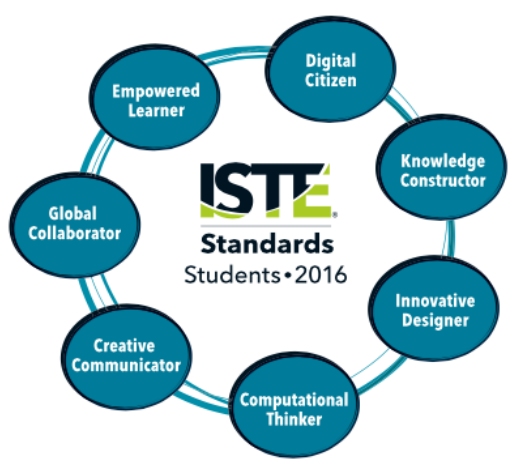

Figure 1. Seven aspects of teaching to the digital native [11]

According to ISTE, Computational Thinker means students could develop and integrate their ability to understand and solve the problems using technological methods. Students perform technology-assisted methods such as data analysis, abstract models, and algorithmic thinking to explore and find solutions. Digital tools are used to 


\section{International Journal of Applied Sciences and Smart Technologies}

Volume 2, Issue 2, pages 197-208

p-ISSN 2655-8564, e-ISSN 2685-9432

analyze and identify relevant real-world data, break problems into parts, extract information, and develop a descriptive model to understand problems and solve problems using computer programming or applications [11].

These aspects showed that the abstraction thinking process with computer assistance could increase the human capabilities to face daily life problems.

\section{The Future of Learning}

We agreed that internet technology could be a possible way to overcome the educational process's difficulty in the pandemic era. Using this kind of technology, teachers could deliver the materials and reach the students wherever they are. E-learning becomes the most effective learning technique. However, in the real context, we discover many aspects should be considered. This section discussed the teaching methods related to technologies and what we should do when implementing the method.

We recognized some terms in the education field that should be known first when discussing teaching methods related to the modern world and technology.

\subsection{E-learning.}

Electronic learning (e-learning) is a type of education where the medium of instruction in computer technology. Using e-learning, teachers, and students could create, store, access, and interact with the digital materials over the Internet [12]. Although e-learning is being used in teaching, it has yet to gain acceptance. One reason to use e-learning is that the traditional classroom cannot meet the present-day world's needs as modern technologies change the ways we learn [13]. It is still believed that elearning technologies can enhance the effectiveness of teaching. When the technology is implemented, teachers must use various learning resources to support learners using ICT. At least four components should be mentioned as resources in e-learning.

\section{A. Learning Management System}

Learning Management System (LMS) assists teachers and students in managing their courses on the e-learning system. OVAREP (Observatoire des ressources multimedias) defined, "the LMS e-learning platform is a computing device that groups several tools and ensures the educational lines. Across dedicated platforms to the ODL (open and 


\section{International Journal of Applied Sciences and Smart Technologies}

Volume 2, Issue 2, pages 197-208

p-ISSN 2655-8564, e-ISSN 2685-9432

distance learning), all conduits are preserved and expanded for the learner, tutor, coordinator, and administrator within the e-learning platform" [14].

The most and the biggest LMS offered various subjects from famous universities worldwide is the Massive Open Online Course (MOOC) [15]. Even though Kloft et al., in their study, claimed that some enrolled students drop out of their selected study, the study described MOOC's significant role in learning the modern system [16]. Moodle is another example of open source LMS [17]. It provides all the sophisticated high-level functionality of an educational Course Management System. Colleges and Universities have chosen this kind of LMS, such as Moodle, to deliver courses online. Every subject can be made exciting and interactive with the help of CMS.

We concluded that e-learning is anything to do with computer technology to provide teaching and learning materials where the interaction between teachers and students has happened through ICT. Although e-learning is being used in teaching, it has yet to gain acceptance. Many schools have used ICT or ILT (information learning technology) to make learning more enjoyable and exciting. We also recognized that integrating technology into the curriculum causes stress and teacher burnout as they put more and more effort to meet the Standards. Nevertheless, we still believe that e-learning technologies can enhance the effectiveness of teaching.

\section{B. The Internet}

The Internet is being used as a significant teaching resource. The Broadband has enabled users to access information from hundreds of websites using search engines such as Google to research, create their web pages like HTML (Hyper Text Markup Language), and make their blogs [18]. These websites provide learners with education channels. It enables students to practice their reading, writing, listening, and speaking skills in languages with interactive activities and games and provide intensive and extensive subject-specific lesson exercises. It helps learners create self-tests, enabling them to monitor, record, and improve their progress [19].

\section{Computers or Laptops}

Computers and laptops are a widespread tool in our lives. The devices are used as the primary tool in e-learning, where teachers and students access the materials through them. With the introduction of wireless technology, learning can be done both inside 


\section{International Journal of Applied Sciences and Smart Technologies}

Volume 2, Issue 2, pages 197-208

p-ISSN 2655-8564, e-ISSN 2685-9432

and out of class. The teacher can add variety to teaching with audio-visual material and multimedia, thereby providing an inclusive, equitable, and motivating learning environment [20]. Some software allows learners and teachers to create quality documents such as Microsoft Office. There is other specialist software like Photoshop, Moviemaker, and Macromedia Dream-weaver, which are popular with learners as they experiment with it creatively in their specialist fields. Computers and Laptops become the primary device for student's and teacher's interaction and express their idea.

\subsection{A New Learning Media}

\section{A. Gamified Learning}

Kapp defined Gamification is "using game-based mechanics, aesthetics and game thinking to engage people, motivate action, promote learning, and solve problems." [21]. Some game features could be mentioned: users, challenges, or tasks to perform and progress towards defined objectives; points because of executing tasks. Gamification learning means using the game's ideas and is applied to a different context of the games for increasing motivation and commitment in a learning atmosphere. Elearning, based on modern ICT, creates favorable conditions for the implementation of Gamification - the processes of processing students' data and tracking their progress are automated, and software tools can generate detailed reports. Implementation of game elements in education is logical since some facts are typical for games and training.

There are many tools for Gamification. Some of them are web-based (cloud services) and do not require particular software installation and allow access anytime and from any location. Among the most popular gamification tool is Kahoot!, Duolingo, ClassDojo, and Goalbook. Some of these tools are a free plugin to WordPress that automatically creates different achievement types and pages needed to set up a badging system.

\section{B. Social Media}

Recently, the use of Social Media in education has been increasing. Most teachers use a heutagogy approach for teaching and learning [22]. Students and digital natives spend much time on social media. Integrating Social Media apps into learning methodologies is among the most innovative ways. It will be connecting students to curriculum, learning resources, and one another. 


\section{International Journal of Applied Sciences and Smart Technologies}

Volume 2, Issue 2, pages 197-208

p-ISSN 2655-8564, e-ISSN 2685-9432

Creating a Facebook or WhatsApp group specifically for the class group to post discussion topics or develop unique virtual classroom Twitter hashtags students can use to discuss lessons or ask questions. This group application is a powerful tool to deliver materials since students and teachers access these apps frequently.

\section{Digital Content}

It is challenging and an excellent way for students to display their creative talents and convert them into a digital format. Students can express and provide their opinions through blogs, videos, podcasts, and other digital art when asked to answer real-world

problems. Respecting each student's individuality and needs for creative expression helps them flourish as learners [23].

Implementing digital content brings students' presentations to life by incorporating visual effects, photos, videos, and music into them. Developing slideshows and digital presentations, playing music or a video for background and context while presenting, or by inviting virtual guest speakers to engage with the class via programs designed for conference calls such as Zoom, Skype, Google Meet are all fun and creative ways to boost engagement with lessons while teaching the benefit of technology and multimedia use.

\section{Virtuals Labs}

Virtual reality technology is applied in education and teaching. Virtual reality technology can create virtual training bases, virtual components, and equipment, which can generate new devices according to actual needs, and virtual reality has specific immersions and interactions. In virtual reality, learners can perform role-playing and develop skills to exercise more efficiently. There is no risk in the virtual training system. Learners can practice repeatedly and, finally, master skills. However, there is a difference between the virtual training system and the real environment, during the process of using the virtual system to perform system skills, the process should be emphasized.

Depending on virtual reality technology, virtual labs can also be realized. A virtual laboratory is a reproduction of a real laboratory and can also realize a laboratory's virtual concept. Compared with the traditional laboratory, the advantage is more pronounced. The first is to create a virtual reality hardware device to complete the 


\section{International Journal of Applied Sciences and Smart Technologies}

Volume 2, Issue 2, pages 197-208

p-ISSN 2655-8564, e-ISSN 2685-9432

experiment. The second is to avoid the risks that exist in real experiments and to upgrade the laboratory.

Virtual reality technology has played an auxiliary role in education, allowing teachers to liberate themselves from the original and relatively complicated teaching equipment and create false impressions. It allows some teachers to think that students can finish learning by using virtual reality technology, and teachers' role is weakened.

\section{Discussions}

It is no doubt that technologies, primarily ICT, could provide a significant role in replacing traditional in-class teaching amid the COVID-19 pandemic. It is believed that using technology will produce these advantages such as improving the quality of learning, reducing the cost of education, and enhancing teacher-students interaction become more significant. However, after nearly seven months of us undergoing the COVID-19 pandemic, several problems emerge regarding online learning. To overcome the issues, some suggestions are listed below.

\section{A. Infrastructure}

For the third world countries, infrastructure could be the first barrier in implementing e-learning. Hardware and software for the learning system are expensive. The learning materials should be delivered through the Internet, and in some countries, the price of Internet bandwidth is also costly.

Government intervention is required by making a new regulation on the use of internet bandwidth data. Furthermore, teachers at schools or universities should be creative produce learning materials using various kinds of technology using a little Internet bandwidth data such as avoid using streaming apps, videos, or movies.

\section{B. Learning Content}

Creating learning content is difficult and takes time. Students are not satisfied when teachers delivered learning materials only in a PowerPoint format or a PDF file format. Teachers are needed to be creative in content creation. Use interactive learning methods, therefore finding interactive ways of learning such as games, crossword puzzles, dramas, and self-expression videos. 


\section{International Journal of Applied Sciences and Smart Technologies}

Volume 2, Issue 2, pages 197-208

p-ISSN 2655-8564, e-ISSN 2685-9432

\section{Resources}

Human is unique. We are different from each other. It should be reminded that not all teachers have the same ability in e-learning, so do the students. Even though we are separated physically, however, we try to interact with others personally. Collaboration between teachers is the key. Creating learning content must not be done alone. We can ask our colleagues to help if we are not accustomed to creating digital content such as videos, games, or animations. Encourage the students to work together with friends. Teamwork is much appreciated

\section{Delivery System}

Delivery systems are the crucial point in e-learning. One crucial aspect of the delivery system is to determine the material delivery by synchronous or asynchronous systems. In some ways, the synchronous system is better but more expensive related to e-learning technology. The student's conditions come first. Sometimes, it is easy to find an Internet connection; however, in other areas is problematic. Some students have computers and laptops, but others have not. The most important point is that students get their learning materials quickly and cheaply.

\section{Conclusions}

The COVID-19 pandemic has opened a new way of thinking in learning methodologies. Technology in future learning could be seen as new tools to enhance delivering materials and learning content. Computers and other technologies (including virtual labs) will never replace teachers. However, teachers could incorporate technological tools to enhance their teaching quality and their students' learning. These new technological tools create a new way of thinking in teaching. Some efforts should be spent to develop, publish, and incorporate in educational sectors. Suppose we wish to improve the teaching performance. In that case, we must reinforce the new technological tools' pedagogical facets and develop programs that incorporate these new tools as integral elements of the teaching practice rather than external technical aids to the teaching and learning process. It needs to be concerned to develop the appropriate 


\section{International Journal of Applied Sciences and Smart Technologies}

Volume 2, Issue 2, pages 197-208

p-ISSN 2655-8564, e-ISSN 2685-9432

pedagogy to support the new ICT so they can collaborate to deliver a new way of learning for the digital native student.

\section{Acknowledgement}

The author thanks colleagues at the Faculty of Science and Technology, Sanata Dharma University, Yogyakarta, Indonesia for the assistance and encouragement.

\section{References}

[1] R.M. Viner, S.J. Russell, H. Croker, J. Packer, J. Ward, C. Stansfield, et al. "School closure and management practices during coronavirus outbreaks including COVID-19: a rapid systematic review." The Lancet Child \& Adolescent Health, 2020.

[2] W. Van Lancker and Z. Parolin. "COVID-19, school closures, and child poverty: a social crisis in the making." The Lancet Public Health, 5 (5) e243-e244, 2020.

[3] F.M. Reimers and A. Schleicher. "A framework to guide an education response to the COVID-19 Pandemic of 2020." OECD 2020.

[4] S. Hase. "Heutagogy and e-learning in the workplace: Some challenges and opportunities." Impact: Journal of Applied Research in Workplace E-Learning, $1(1), 43-52,2009$.

[5] L.M. Blaschke. "Heutagogy and lifelong learning: A review of heutagogical practice and self-determined learning." The International Review of Research in Open and Distributed Learning, 13 (1), 56-71, 2012.

[6] S. Hase and C. Kenyon, Self-Determined Learning: Heutagogy in Action: A\&C Black, 2013.

[7] S. Hase and C. Kenyon. "Heutagogy: A child of complexity theory." Complicity: An International Journal of Complexity and Education, 4 (1), 111-118, 2007.

[8] C. Englund, A.D. Olofsson and L. Price. "Teaching with technology in higher education: understanding conceptual change and development in practice." Higher Education Research \& Development, 36 (1), 73-87, 2017.

[9] J.M. Wing. "Computational thinking." Communications of the ACM, 49 (3), 33-35, 2006. 


\section{International Journal of Applied Sciences and Smart Technologies}

Volume 2, Issue 2, pages 197-208

p-ISSN 2655-8564, e-ISSN 2685-9432

[10] J. Cuny, L. Snyder and J. Wing, Computational Thinking: A Definition.(in press). 2010.

[11] ISTE. [cited on 4 October 2020]; Available from: https://iste.org/standards/forstudents, 2020.

[12]A.W. Bates and T. Bates, Technology, e-learning and distance education. Psychology Press, 2005.

[13] S. Kuraishy and M.U. Bokhari. "Teaching effectively with e-learning." International Journal of Recent Trends in Engineering 1 (2), 291, 2009.

[14] D.S. Walker, J.R. Lindner, T.P. Murphrey, K. Dooley. "Learning management system usage." Quarterly Review of Distance Education 17 (2), 41-50, 2016.

[15]MOOC. [cited on 4 October 2020]; Available from: https://www.mooc.org/, 2020.

[16] M. Kloft, F. Stiehler, Z. Zheng, N. Pinkwart. "Predicting MOOC dropout over weeks using machine learning methods." Proceedings of the EMNLP 2014 Workshop on Analysis of Large Scale Social Interaction in MOOCs. 2014.

[17] Moodle [cited on 4 October 2020]; Available from: https://moodle.org/, 2020.

[18]A. Gunasekaran, R.D. McNeil and D. Shaul, E-learning: research and applications. Industrial and commercial training, 2002.

[19] D. Smith and G. Hardaker. "E-learning innovation through the implementation of an internet supported learning environment." Journal of Educational Technology \& Society 3 (3), 422-432, 2000.

[20]I. Han and W.S. Shin. "The use of a mobile learning management system and academic achievement of online students." Computers \& Education 102, 79-89, 2016.

[21] K.M. Kapp, The Gamification of Learning and Instruction: Game-Based Methods and Strategies for Training and Education. John Wiley \& Sons, 2012.

[22] L.M. Blaschke, "Using social media to engage and develop the online learner in self-determined learning." Research in Learning Technology 22, 21635, 2014.

[23] M. Weller and T. Anderson. "Digital resilience in higher education." European Journal of Open, Distance and E-Learning 16 (1), 53, 2013. 